\title{
PENGARUH INTRADYALITIC EXERCISE TERHADAP PENURUNAN NYERI PASIEN HEMODIALISA RUTIN DI UNIT HEMODIALISA RSUD Dr. TJITROWARDOJO PURWOREJO
}

\author{
Oleh; \\ Wiwit Sugiarti ${ }^{1)}$, Sri Nabawiyati Nurul Makiyah ${ }^{2)}$, Azizah Khoiriyati ${ }^{3)}$ \\ 1 Mahasiswa Program Magister Keperawatan UMY, Email; wwtsugiarti@gmail.com \\ 2) Dosen Program Magister Keperawatan UMY Email; wwtsugiarti@gmail.com \\ 2) Dosen Program Magister Keperawatan UMY Email; wwtsugiarti@gmail.com
}

\begin{abstract}
ABSTRAK
Latar belakang; Nyeri muskuloskeletal merupakan gejala yang dialami pasien gagal ginjal kronik yang menjalani hemodialisa.Manajemen nyeri dapat menggunakan distraksi relaksasi konvensional dan intradialytic exercise. Penelitian ini bertujuan untuk mengetahui efektivitas Intradialytic exercise dalam menurunkan nyeri pada pasien hemodialisa rutin di Unit Hemodialisa Rumah Sakit Umum Daerah Dr. Tjitrowardojo Purworejo.

Metode; Rancangan penelitian yang digunakan eksperimen semu dengan desain pretestposttest with control group. Respondennya 36 orang, terdiri dari 18 pasien yang diberi Intradialytic exercise sebagai kelompok intervensi dan 18 pasien lainnya hanya diberikan distraksi-relaksasi konvensional sebagai kelompok kontrol. Pengukuran nyeri menggunakan Visual Analog Scale. Analisis datanya menggunakanPaired t Testdan Independent Sample $t$ Test.

Hasil; Hasil penelitian didapatkan perbedaan penurunan yang signifikan terhadap skor nyeri pre dan postes pada kelompok baik intervensi dan kelompok kontrol dengan $p$ value 0,000 ( $p<0,005$ dan metode Intradialytic exercise lebih efektif dalam menurunkan skor nyeri dibandingkan metode distraksi-relaksasi konvensional pada pasien HD rutin dengan $p$ value $0,000(\mathrm{p}<0,005)$.
\end{abstract}

Kata kunci: Intradialytic Exercise, Nyeri 


\section{PENDAHULUAN}

Gagal Ginjal Kronik (GGK) menjadi penyebab utama pasien menjalani terapi hemodialisa (HD).HD menjadi alternatif utama terapi pengganti fungsi ginjal bagi pasien GGK dikarenakan dari faktor biaya lebih murah dan risiko terjadinya perdarahan lebih rendah jika dibandingkan dengan dialisis peritoneal (Markum, 2006).

Jumlah HD rutin dari tahun 2007 sampai 2014 mengalami peningkatan di Indonesia. Pada tahun 2007 jumlah pasien HD tercatat sebanyak 140.972 orang dan terjadinya peningkatan jumlah pasien HD tahun 2014 mencapai 703.139 orang (Indonesia Renal Registry, 2014).Total jumlah pasien HD baru pada tahun 2010 sebanyak 9.649 orang dan pasien HD aktif sebanyak 5.184 orang.Berdasarkan profil RSUD Dr. Tjitrowardojo terdapat peningkatan pasien yang menjalani HD di ruang HD setiap tahun yaitu pada tahun 2011 sebanyak 556 orang, 2012 sebanyak 836 orang dan pada tahun 2013 menjadi 918 orang.

Pasien yang menjalani HD mengalami gejala komplikasi seperti nyeri yang berdampak terhadap kualitas hidup bahkan dapat menimbulkan kematian(Septiwi, 2013; PERNEFRI, 2012; Murtagh et al., 2007). Gangguan nyeri muskuloskeletalberupa nyeri sendi, nyeri punggung, dan kram otot berkaitan dengan gangguan mineral dan tulang akibat GGK yang mempengaruhi tingginya kadar hormon paratiroid walaupun terdapat faktor lain yang mempengaruhi seperti faktor demografi, gaya hidup, biologi, psikologi, dan dialisis (Sabbatini, 2003).

Pada beberapa penelitian terdapat manajemen untuk mengatasi nyeri yaitu dengan cognitive behavioral therapy (CBT), acupressure, physical exercise.Physical exerciseyang dilakukan salah satu dengan Intradialytic exercise, memiliki efek menguntungkan yaitu dapat memperlambat penurunan fungsi ginjal (Chen IRet al., 2014; Greenwoodet al., 2015; Robinsonet al., 2014). Selain itu, program Intradialytic exercisetelah terbukti memiliki efek cukup positif pada kualitas tidur pasien dengan gangguan ginjal kronik yang dilakukan HD (Yanget al., 2012; Afshar et al., 2011).

Intradialytic exercise yang dilakukan terus menerus penting untuk pasien HD karena memberikan manfaat bukan sekedar peningkatan fungsional fisik namun juga mampu meningkatkan kadar oksigen dan menguatkan kekuatan otot, status nutrisi, hematological indexes, mengurangi depresi, dan mempertahankan dan meningkatkan kesehatan tubuh secara keseluruhan (Tae-Du Jung, 2011; Fritz, 2005; Potter \& Perry, 2006). Intradialytic exercisesecara signifikan meningkatkan kekuatan otot dan ukuran miofiber pada pasien GGK (Adam et al, 2006; Johansen, 
2005). Adanya pengurangan aktivitas akan dapat menyebabkan penurunan kekuatan dan lebih lanjut mengakibatkan atrofi pada otot.Teknik latihan intradialisis dengan intradialytic stretching exercise dapat menurunkan skala nyeri dari skala sangat nyeri menjadi nyeri sedang (Issac, 2016).

Menurut standar akreditasi rumah sakit (JCI, 2011), manajemen nyeri merupakan salah satu elemen penilaian yang dipersyaratkan untuk dipenuhi rumah sakit, karena pasien berhak mendapatkan asassementdan pengelolaan rasa sakit yang tepat. Hal ini menuntut pihak rumah sakit untuk dapat melakukan manajemen nyeri yang tepat, termasuk pada pasien HD.

\section{METODE}

Penelitian ini merupakan penelitian eksperimen, menggunakan desain ekperimen semu (quasi experiment) dengan rancangan pretest-posttest with control group. Jumlah sampel sebanyak18 yaitu besar sampel untuk kelompok kontrol sebesar 18 sampel dan besar sampel untuk kelompok treatment sebesar 18 sampel, sehingga jumlah total sampel yang diperlukan dalam penelitian ini adalah 36 responden. Pengambilan sampel dalam penelitian ini adalah dengan cara quota sampling. Visual Analog Scale (VAS) untuk mengukur skor nyeri responden. Untuk mengukur skor nyeri responden.analisis komparasi parametris
Paired $t$ Test dan Independent Sample $t$ Test.

\section{HASIL}

\section{Karakteristik responden}

Tabel; Demografi Responden

\begin{tabular}{lcccccc}
\hline \multicolumn{1}{c}{ Kondisi } & \multicolumn{2}{c}{ Intervensi } & \multicolumn{2}{c}{ Kontrol } & \multicolumn{2}{c}{ Total } \\
Demografi & $\mathbf{f}$ & $\mathbf{\%}$ & $\mathbf{f}$ & $\boldsymbol{\%}$ & $\mathbf{f}$ & $\boldsymbol{\%}$ \\
\hline Jenis Kelamin & & & & & & \\
Laki-laki & 11 & 61,1 & 11 & 61,1 & 22 & 61,1 \\
Perempuan & 7 & 38,9 & 7 & 38,9 & 14 & 38,9 \\
\hline \multicolumn{1}{c}{ Jumlah } & $\mathbf{1 8}$ & $\mathbf{1 0 0}$ & $\mathbf{1 8}$ & $\mathbf{1 0 0}$ & $\mathbf{3 6}$ & $\mathbf{1 0 0}$ \\
\hline Usia & & & & & &
\end{tabular}

\section{Usia}

$\begin{array}{lllllll}<40 \text { tahun } & 3 & 16,7 & 4 & 22,2 & 7 & 19,4 \\ 40-55 \text { tahun } & 7 & 38,9 & 10 & 55,6 & 17 & 47,2 \\ >\text { 55 tahun } & 8 & 44,4 & 4 & 22,2 & 12 & 33,3\end{array}$

\begin{tabular}{lllllll}
\hline Jumlah & 18 & 100 & 18 & 100 & 36 & 100
\end{tabular}

\section{Pendidikan}

\begin{tabular}{lcccccc} 
SD & 3 & 16,7 & 4 & 22,2 & 7 & 19,4 \\
SMP & 3 & 16,7 & 1 & 5,6 & 4 & 11,1 \\
SMA & 7 & 38,9 & 11 & 61,1 & 18 & 50 \\
D3 & 1 & 5,6 & 1 & 5,6 & 2 & 5,6 \\
S1 & 4 & 22,2 & 1 & 5,6 & 5 & 13,9 \\
\hline \multicolumn{1}{r}{ Jumlah } & $\mathbf{1 8}$ & $\mathbf{1 0 0}$ & $\mathbf{1 8}$ & $\mathbf{1 0 0}$ & $\mathbf{3 6}$ & $\mathbf{1 0 0}$
\end{tabular}

\section{Pekerjaan}

$\begin{array}{lllllll}\text { Bekerja } & 12 & 66,7 & 13 & 72,2 & 25 & 69,4\end{array}$

$\begin{array}{lllllll}\text { Tidak Bekerja } \quad 6 & 33,3 & 5 & 27,8 & 11 & 30,6\end{array}$

\begin{tabular}{lllllll}
\hline Jumlah & 18 & 100 & 18 & 100 & 36 & 100
\end{tabular}

\section{Pernikahan}

$\begin{array}{lllllll}\text { Menikah } & 16 & 88,9 & 18 & 100 & 34 & 94,4\end{array}$

$\begin{array}{lllllll}\text { Belum } & 2 & 11,1 & 0 & 0 & 2 & 5,6\end{array}$

menikah/janda/

duda

$\begin{array}{lllllll}\text { Jumlah } & 18 & 100 & 18 & 100 & 36 & 100\end{array}$


Berdasarkan Tabel 1 tersebut di atas, secara demografis dapat diketahui bahwa responden baik kelompok intervensi maupun kontrol berjenis kelamin laki-laki, berusia 40-55 tahun dan di atas 55 tahun, berpendidikan SMA, menjalani hemodialisa rutin tetap bekerja, berstatus menikah (terikat dalam pernikahan).
2. Pengaruh Intradialytic exercise terhadap Penurunan Skor Nyeri

Berdasarkan hasil analisis komparasi menggunakan rumus Paired t Test dan Independent Sample $t$ Tes tentang efektivitasIntradialytic exerciseterhadap penurunan skor nyeri pasien hemodialisa rutin di Unit Hemodialisa RSUD Dr. Tjitrowardojo Purworejo

Tabel 3; Hasil Analisis Bivariat Efektivitas Intradialytic exercise terhadap Penurunan Skor Nyeri Responden

\begin{tabular}{|c|c|c|c|c|}
\hline \multirow{2}{*}{ Kelompok Responden } & \multicolumn{3}{|c|}{ Mean } & Komparasi Skor \\
\hline & Pretes & Postes & Penurunan & Nyeri Postes-Pretes \\
\hline K. Intervensi & 5,83 & 1,56 & 4,28 & $p=0,00$ \\
\hline$\overline{\text { K. Kontrol }}$ & 5,67 & 3,67 & 2 & $p=0,00$ \\
\hline
\end{tabular}

Tabel 3 tersebut di atas menunjukkan untuk kelompok intervensi terjadi penurunan skor nyeri rata-rata sebesar 4,28 (dari pretes sebesar 5,83 sampai postes sebesar 1,56). Penurunan skor nyeri pada kelompok intervensi tersebut ternyata signifikan, terbukti dengan diperolehnya nilai signifikansi $p=0,000$ (lebih kecil dibandingkan 0,05). Dengan demikian terbukti bahwa pada kelompok intervensi terjadi penurunan skor nyeri yang signifikan dari pretes sampai postes. Pada kelompok kontrol terjadi penurunan skor nyeri rata-rata sebesar 2 (dari pretes sebesar 5,67 sampai postes sebesar 3,67). Penurunan skor nyeri pada kelompok kontrol tersebut ternyata juga signifikan, terbukti dengan diperolehnya nilai signifikansi $p=0,000$ (lebih kecil dibandingkan 0,05). Dengan demikian terbukti bahwa pada kelompok kontrol terjadi penurunan skor nyeri yang signifikan dari pretes sampai postes.

Selanjutnya hasil analisis komparasi penurunan skor nyeri antara kelompok intervensi dengan kelompok kontrol ternyata juga signifikan, terbukti dengan diperolehnya nilai signifikansi $p=0,000$ 
(lebih kecil dibandingkan 0,05). Dengan demikian terbukti terdapat perbedaan penurunan skor nyeri yang signifikan antara kelompok intervensi dengan kelompok kontrol, artinya penurunan skor nyeri. Pada kelompok intervensi lebih tinggi dibandingkan kelompok kontrol.

Berdasarkan hasil analisis bivariat tersebut di atas, dapat disimpulkan bahwa meskipun dua metode yang digunakan dalam penelitian ini yaitu metode Intradialytic exercise yang diterapkan pada kelompok intervensi serta metode distraksi-relaksasi konvensional yang diterapkan pada kelompok kontrol semuanya efektif dalam menurunkan nyeri pasien HD rutin di Unit Hemodialisa RSUD Dr. Tjitrowardojo Purworejo, namun tingkat penurunannya lebih tinggi menggunakan metode Intradialytic exercise. Dengan kata lain metode Intradialytic exercise lebih efektif dalam menurunkan nyeri pasien HD rutin dibandingkan metode distraksi-relaksasi konvensional yang sampai saat ini masih diterapkan di Unit Hemodialisa RSUD Dr. Tjitrowardojo Purworejo.

\section{PEMBAHASAN}

\section{Karakteristik Responden}

Karakteristik responden pada penelitian ini mayoritas laki-laki yang mendukung terjadinya kejadian GGK. Laki-laki lebih cenderung mengunakan suplemen yang menimbulkan penyakit diabetes melitus yang menjadi faktor resiko terjadinya GGK (Latifah, 2016).Kemampuan laki-laki untuk melakukan senam atau exercise lebih optimal dibandingkan dengan wanita karena memiliki kemampuan otot yang lebih kuat sehingga dapat mempengaruhi keberhasilan senam (Patandianan, 2015).

Menurut Handayani (2017), usia erat kaitannya dengan prognose penyakit dan harapan hidup pasien GGK dengan HD. Pasien GGK dengan HD yang berusia 40 atau lebih cenderung mengalami berbagai komplikasi yang memperberat fungsi ginjal dibandingkan dengan yang berusia di bawah 40 tahun. Kecenderungan mengalami komplikasi pada pasien GGK dengan HD akan meningkat pada usia di atas 55 tahun. Selain itu penelitian yang dilakukan Simo et al (2015) efek intradialytic exercise pada usia lansia dengan intensitas sedang dapat meningktan kekuatan otot hal ini membuktikan bahwa intradialytic exercise dapat di lakukan pada usia diatas $>45$ tahun.

Faktor pendidikan dan status pekerjaan sangatlah penting dalam menjalankan intradialityc exercise, 
semakin tinggi pendidikan dan status pekerjaan bekerja dapat meningkatkan kemampuan seorang dalam menerima informasi mengenai pentingnya tindakan intaradialityc exercise sehingga dapat dilakukan dengan efektif (Zhang, 2006; Fred , 2010; W.Kip 2010).

2. Pengaruh Pengaruh Intradialytic exercise terhadap Penurunan Skor Nyeri

Hasil penelitian secara inferensial membuktikan bahwa metode Intradialytic exercise lebih efektif dalam menurunkan nyeri pasien HD rutin dibandingkan metode distraksirelaksasi konvensional yang sampai saat ini masih diterapkan di Unit Hemodialisa RSUD Dr. Tjitrowardojo Purworejo. Efektifnya metode Intradialytic exercise dalam menurunkan nyeri pasien HD rutin pada dasarnya berkaitan erat dengan pengurangan derajat faktor penyebab terjadinya komplikasi nyeri pada pasien GGK yang menjalani HD apabila metode Intradialytic exercise dilakukan sesuai SOP.

Selama jalannya penelitian tidak terdapat kendala yang berarti, seperti yang diungkapkan Painter (2010) Intradialytic exercise pada pasien hemodialisa harus dihentikan apabila pasien mengalami sesak nafas, nyeri dada dan tertekan, nadi irreguler,mual,kaki kram, pusing, rasa sakit atau tertekan dileher dan rahang, kelemahan, dan pandangan kabur. Responden kelompok intervensi melakukan latihan sesuai dengan prosedur dan waktu yang ditentukan, ini disebabkan karena pasien yang menjadi responden telah melalui kriteria inklusi dan eksklusi yang ditentukan.

Telah dipaparkan sebelumnya bahwa nyeri adalah suatu pengalaman sensorik dan emosionalyang tidak menyenangkan dan berhubungan dengan kerusakan jaringan yang aktual atau potensial (Tamsuri, 2007).Sumber nyeri penting pada pasien GGK yang menjalani HD diantaranya adalah gangguan muskuloskeletal yang disebabkan oleh sekresi parathormon dari kelenjar parathyroid meningkat yang berpotensi mengganggu keseimbangan kalsium dan fosfat dalam tulang, sehingga terjadi komplikasi nyeri (Liau, 2016).

Sumber nyeri penting lainnya pada pasien GGK yang menjalani HD adalah tingginya kadar asam urat dalam darah. Pada penyakit ginjal kronik terjadi pengurangan massa ginjal dan penurunan fungsi ginjal 
yang menyebabkan gangguan proses

fisiologis ginjal terutama dalam hal ekskresi zat-zat sisa salah satunya asam urat (Silbernagl \& Lang, 2012).

Mula-mula proses tersebut dapat terkompensasi oleh daya cadang ginjal yang menggantikan nefron ginjal yang rusak, tetapi proses tersebut hanya sementara dan akhirnya akan terjadi proses maladaptasi dari nefron yang mengkompensasi. Pada laju filtrasi glomerulus $<50 \%$ mulai terjadi peningkatan asam urat serum dan akan terus meningkat seiring dengan penurunan LFG di ginjal, alhasil akan didapatkan keadaan hiperurisemia karena PGK/hiperurisemia sekunder (Putra, 2009).

Hiperurisemia akan mencetuskan pembentukan garam monosodium urat (MSU) pada jaringan dan sendi. Timbunan tersebut kemudian dikenali sistem imun sebagai benda asing, sehingga mengaktifkan mediator inflamasi.Mediator ini menyebabkan kerusakan dan mengaktivasi berbagai sel radang, sehingga timbul peradangan yang mengakibatkan nyeri.

Sumber nyeri penting lainnya pada pasien GGK yang menjalani HD adalah terganggunya metabolisme mineral tulang.Terganggunya metabolisme mineral tulang terutama kalsium, PTH, dan $25(\mathrm{OH}) \mathrm{D}_{3}$ memiliki hubungan yang kuat dengan nyeri yang dialami pasien hemodialisis. Untuk menjaga keseimbangan kalsium, ginjal harus mengekskresikan jumlah kalsium yang sama dengan usus kecil menyerap.

Tulang tidak hanya melayani struktural fungsi tetapi juga menyediakan sistem pertukaran kalsium untuk penyesuaian menit-kemenit tingkat kalsium dalam plasma dan ECF.

Hasil penelitian Raheleh et al., (2013)tentang pengaruh latihan aerobik intradialytic pada efektifitas dialisis pasien HD, persamaan dengan penelitian ini adalah meneliti pengaruh latihan aerobik dan dilakukan pada pasien HD, dengan hasil penelitiandidapatkan efektivitas dialisis meningkat pada akhir bulan pertama dan tetap tinggi selama program pada kelompok latihan ( $\mathrm{p}$ $<0,05)$.

Hasil penelitian sama-sama efektif dilakukan pada pasien HD, dan untuk efektifitas waktu pada penelitian ini waktu dimodifikasi menjadi 30 menit,sedangkan menurut Painter (2010) waktu Intradialytic exercise dilakukan selama 45 menit, dengan pertimbangan waktu lebih sedikit 
yaitu 30 menit maka penelitian ini lebih efektif waktunya.

Menurut Parsonet al., (2006) bahwa latihan fisik yang dilakukan selama dialisis dapat meningkatkan aliran darah pada otot dan memperbesar jumlah kapiler serta memperbesar luas permukaan kapiler sehingga meningkatkan perpindahan urea dan toksin dari jaringan ke vaskuler kemudian dialirkan ke dializer atau mesin hemodialisis.

Latihan fisik dilakukan pada saat pasien menjalani hemodialisis. Latihan dapat dilakukan selama 30 sampai dengan 45 menit dan secara umum diberikan sebelum hemodialisis selesai dilakukan, dengan dasar inilah maka penelitian dilakukan selama 30 menit dengan berbagai pertimbangan antara lain mencegah pasien HD agar tidakmengalami kelelahan,dan hasilnya tetap efektif signifikan menurunkan nyeri.

Perawat harus memperhatikan pemeliharaan kesehatan pasien dengan melakukan latihan fisik diantaranya latihan isometrik otot dan ROM (Range of Motion) pasif-aktif dapat membantu dan mempertahankan kekuatan otot dan fungsi tulang (Brunner \& Suddarth, 2001). Intradialytic exercise pada penelitian ini adalah suatu modifikasi dari
Painter (2010) yang terdiri dari gerakan ROM sederhana dan adanya gerakan flexibility exercise, strengthening exercise, dan cardiovaskuler exercise.

Intradilytic exercise dalam beberapa penelitian melibatkan fisioterapi dan perawat HD dalam menjalankannya (Yurdalan, 2013; Hasan, 2015; Young et al, 2015). Perawat lebih memiliki peran membantu dalam gerakan ROM dan edukasi dalam melakukan Intradilytic exercise (Hasan, 2015; Young et al, 2015)

\section{KETERBATASAN PENELITIAN}

Pada penelitian ini peneliti memiliki keterbatasan hanya melakukan pengukuran pretes-postes nyeri masing-masing satukali, yaitu pertama kali akan dilakukan intervensi (pretes) dan pada akhir penelitian (postes) dikarenakan keterbatasan waktu dan tenaga. Idealnya pengukuran nyeri dilakukan sebelum dan sesudah dilakukan tindakan intervensi (intradialytic exercise dan distraksirelaksasi konvensional) supaya hasilnya tidak bias.Pengukuran nyeri paling tidak dilakukan setiap minggu agar diketahui perkembangannya secara kontinyu.Untuk penelitian selanjutnya disarankan melakukan pengukuran nyeri sebelum dan 
sesudah dilakukan tindakan intervensi agar hasilnya akurat.

\section{DAFTAR PUSTAKA}

Adams, G. R., \& Vaziri, N. D. (2006). Skeletal muscle dysfunction in chronic renal failure: effects of exercise. American Journal of Physiology-Renal Physiology, 290(4), F753-F761.

Handayani, R. S., \& Rahmayati, E. (2017). Faktor Faktor Yang Berhubungan dengan Kualitas Hidup Pasien Chronic Kidney Disease (CKD) yang Menjalani Hemodialisis. Jurnal keperawatan, 9(2), 238-245.

Indonesia, P. N. (2011). 4th Report of indonesian renal registry.

Markum, S.M.H (2006). Gagal Ginjal Akut. Buku Ajar Ilmu Penyakit Dalam. Jakarta : EGC

Painter, P., \& Marcus, R. L. (2010). Assessing physical function and physical activity in patients with CKD. Clinical Journal of the American Society of Nephrology, CJN-06590712.

Patandianan, R. F., Wungouw, H. I., \& Marunduh, S. (2015). Pengaruh
Latihan Beban Terhadap Kekuatan

Otot Lansia. Jurnal eBiomedik, 3(1).

Sabbatini, M., Crispo, A., Pisani, A., Ragosta, A., Cesaro, A., Mirenghi, F., ... \& Federico, S. (2003). Zaleplon improves sleep quality in maintenance hemodialysis patients. Nephron Clinical Practice, 94(4), c99-c103.

Septiwi, C. (2013). Pengaruh Breathing Exercise Terhadap Level Fatigue Pasien Hemodialisis Di RSPAD Gatot Subroto Jakarta. Jurnal Keperawatan Soedirman, 8(1), 1421.

Tamsuri, A. (2007). Konsep dan penatalaksanaan nyeri. Jakarta: EGC, 1-63.

W.Kip Visculs.(2010). Smoke-Filed Room:A Ppostmortem on Tabacco Deal.The University of Chicago Press.

Zhang, L., Samet, J., Caffo, B., \& Punjabi, N. M. (2006).Cigarette smoking and nocturnal sleep architecture.American Journal of Epidemiology, 164(6), 529-537. 